\title{
MEASUREMENTS RESULT ANALYSIS OF DEFORMATION CHARACTERISTICS OF TRANSITION ZONES ON THE MODERNIZED LINE PÚCHOV - POVAŽSKÁ TEPLÁ
}

\author{
Libor IŽVOLT ${ }^{1}$, Peter DOBEŠ ${ }^{1, *}$ \\ ${ }^{1}$ Faculty of Civil Engineering, University of Zilina, Univerzitna 8215/1, 01026 Zilina, Slovakia. \\ * corresponding author: peter.dobes@uniza.sk
}

\begin{abstract}
The current trend in Europe and worldwide is to support the development of so-called green transport, characterized by lower energy consumption and lower $\mathrm{CO}_{2}$ emissions. Rail transport meets these conditions and therefore considerable funding is being spent not only on the construction of high-speed lines but also on the modernization of existing railways, especially those forming part of the trans-European corridors.

Three corridors of the basic TEN-T network pass through the territory of the Slovak Republic. In the Žilina Region, there are two corridors, Balt - Adriatic and Rhine - Danube, with a common section Púchov Žilina, which is currently being modernized. It is a known fact that railway lines often show a greater degree of degradation in the transition zones between the earthwork and the structures of subballast layers. Since every railway infrastructure management aims to minimize maintenance costs, while ensuring the safety and comfort of passengers, it is necessary to pay increased attention also to transiton zones. In this context, the presented paper deals with the analysis of values of deformation characteristics on the modernized line section Púchov - Považská Teplá, which is characterized by several bridge structures and tunnels. The values were obtained within the quality inspection of work in transition zones located between the earthwork and the structures of sub-ballast layers.
\end{abstract}

\author{
Keywords: \\ Railway track; \\ Railway line modernization; \\ Transition zone; \\ Deformation resistance; \\ Static modulus of deformation.
}

\section{Introduction}

Transport creates the necessary preconditions for the standard and efficient functioning of the economy and society as a whole. The creation of a transport system at the required quantitative and qualitative level is a necessary condition for satisfying the transport needs of every country. One of the common goals of the European countries, following the change in the political situation in the late 1980 s and early 1990s, was to create a single pan-European interoperable network that would ensure trade between European countries and, consequently, their economic development.

For this reason, in 1991, the so-called Pan-European Transport Conference attended by representatives of the governments of the countries of Central and Eastern Europe, the countries of the European Union, as well as representatives of other international organizations and institutions was held. The positive consequence of the conference was the adoption of basic criteria for the direction of transport routes, the so-called corridors for the connection of Western Europe with the East, the method of their implementation and financing. The second Pan-European Conference, held in Crete in 1994, was preceded by several regional conferences (Baltic, Barents, Black, Adriatic and Central European initiatives). These conferences contributed to the generalization of the conclusions and recommendations of the II. Pan-European Conference on Transport and the conclusion of the socalled Cretan Declaration, which defined nine multimodal transport corridors. 
The III. Pan-European Conference, which took place in 1997 in Helsinki, increased the number of transport corridors to ten as a result of the break-up of Yugoslavia and adopted a set of general principles for European transport policy [1]. Through the Accord Européen sur les Grandes lignes internationales des Chemin de fer (AGC) [2], which was based on the conclusions of II. and III. PanEuropean Conference, the requirements for the design parameters of the modernized railway line were unified. The line section Púchov - Považská Teplá, which is the subject of the presented article, is a part of the corridors that pass through the territory of Slovakia. This line section is not only part of corridor no. $V$ and its Va branches (Bratislava - Čierna nad Tisou - Lviv) [3], but also the TEN-T corridors, which are the Baltic - Adriatic and Rhine - Danube corridors. After World War II, more than $70 \%$ of lines were renewed in the territory of the Slovak Republic. Since that period, only limited funds were spent on the repair and reconstruction work in railway infrastructure. Due to this, the modernization of the section in question as well as other sections was more than desirable.

The modernization of the Púchov - Považská Teplá line section has been beginning in September 2016. The expected completion is in December 2021. The modernization of this line section of the trans-European corridor also includes its high-quality technical equipment, which will ensure better services and increase railway safety.

The length of the modernized line section is nearly $16 \mathrm{~km}$, while almost the entire section is in a new route due to the unfavourable line layout of the original route (route along the bank of the Nosice Dam). The mentioned section includes two new tunnels (the Diel tunnel with a length of $1,083 \mathrm{~m}$ and the Milochov tunnel with a length of $1,858 \mathrm{~m}$ ), eight railway bridges (the longest with a span of $653 \mathrm{~m}$ leads over the Nosice Dam), four viaducts incorporated into approx. $11.50 \mathrm{~m}$ high embankment body, five new road overpasses, four underpasses for passengers and four culverts. The two local railway stations were also modernized (Považská Bystrica and Považská Teplá, which became a railway stop). With these structures and their extent, the line section ranks among the most technically and financially complex and interesting structures in the history of the Slovak railway infrastructure manager (Railways of the Slovak Republic, abbreviated - ŽSR) [4].

The primary goal of the modernization of railway lines is to ensure a quality and safe track. Following this requirement, the content of the presented paper is an analysis of the measured values of deformation characteristics of the most critical places in terms of the most common failures of the track layout and geometry - the so-called transition zones. Deformation characteristics of transition zones were obtained within the implementation of quality inspection of construction works, carried out by the Department of Railway Engineering and Track Management (DRETM) on the line section Púchov - Považská Teplá (Fig. 1) in 2017 - 2020. The paper content follows up and is a continuation of the paper Analysis of results of deformation characteristics measurements of embankments and transitions zones of a modernised line Považská Teplá - Žilina [5].

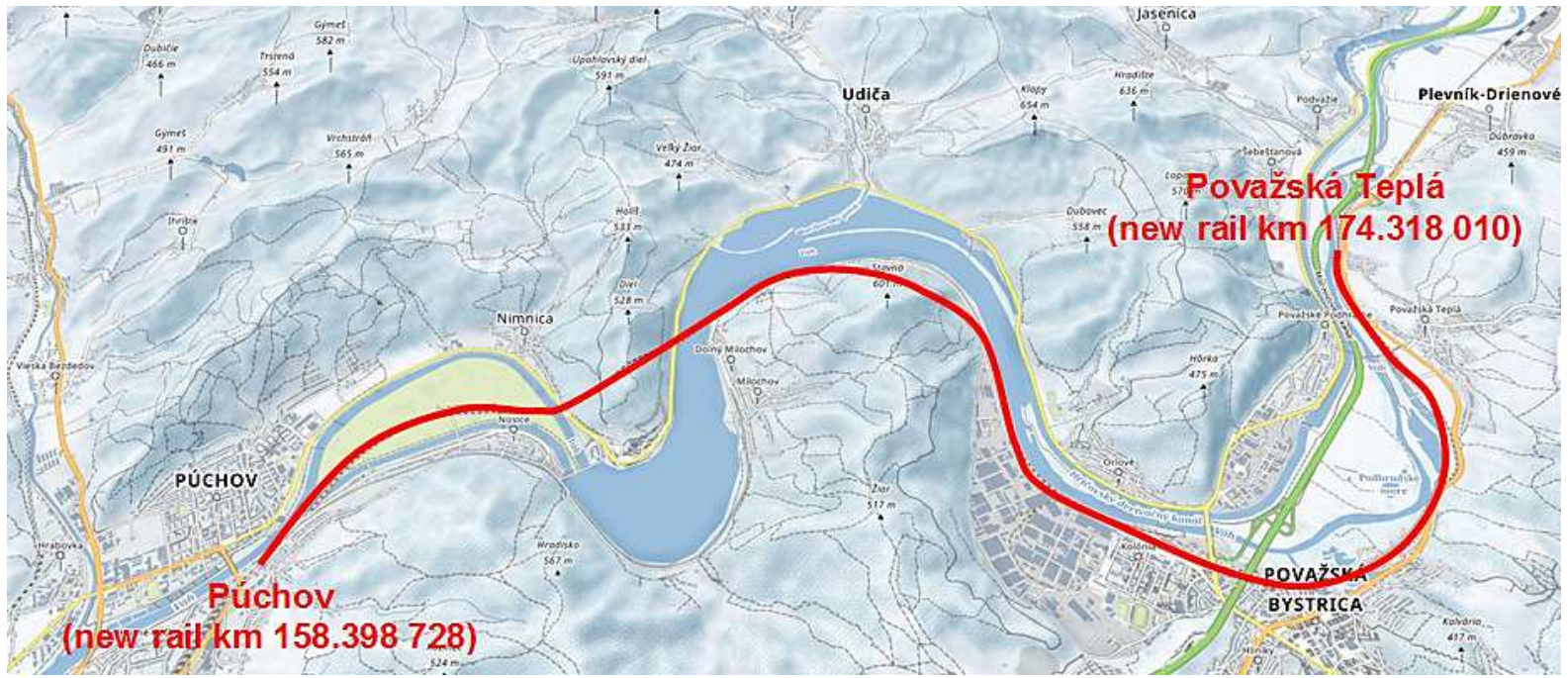

Fig. 1: Modernized section of the line Púchov - Považská Teplá [6].

\section{Materials and methods}

This part of the paper characterizes the test methods for determining the deformation characteristics of transition zones, buildings located on the diagnosed modernized section of the line 
Púchov - Považská Teplá, and also the building materials used for construction of the individual transition zones.

\subsection{Specification of transition zones}

Transition zones can be characterized by the transitions of the earthwork to the structures of the sub-ballast layers - culverts, underpasses, bridges and tunnels. Due to the necessary compensation of the different stiffness between the "soft" earthwork and the "stiff" artificial structure, and in order to reduce the settlement and also the differences in the settlement, transition zones must be arranged between them. This guarantees "unlimited" operational safety, reliability and also sufficient driving comfort. Transition zones are necessary especially in the case of new line construction, or if the line speed on an existing line is increased.

The transition zones must be designed in such a way that the permissible settlements and differences in settlements are observed and that the stiffness of the track is balanced by the continuous stiffness gradation. This results in special requirements for the transition zone, not only for the implementation of backfilling of the structures of sub-ballast layers but also for the subbase of the track superstructure. In case of absence or an incorrectly designed transition zone, it is possible to expect different elastic deflections (drops) of the rail under each axle. They are caused by large differences in the values of the vertical stiffness of the track, due to different mechanical characteristics of the materials built into the railway superstructure and substructure.

An increase in the dynamic effects caused by the train crossing in this case could trigger local track degradation, and thus damage to the track components or crushing of the gravel grains and ultimately different alignment of the track structure settlement. The different settlement of the track in the transition zone is also caused by the fact that, unlike the structures of the sub-ballast layers, their backfill subsoil as well as the gravel layers of backfills are subject to plastic deformations, causing the deflection of rail and vertical irregularities of the track (referred to as a bump or a dip). These conditions can lead to serious errors in the track layout and geometry, when the so-called hanging sleepers occur $[7,8]$.

Based on the results of diagnostic activities carried out by the track geometry inspection vehicle on the ŽSR line infrastructure and continuous diagnostics of transition zones on already modernized railway lines $[9,10]$ it was proved that more frequent faults in the track layout and geometry actually occur in these zones. For this reason, our department decided to cooperate in diagnosing the construction quality of structural layers of transition zones during their construction as part of the implementation of modernization work. At present, DRETM is also solving the grant project VEGA $1 / 0084 / 20$ Numerical and experimental analysis of transition areas of objects of structures of railway superstructures and objects of formation substructure, where the input parameters for numerical modeling of various material and structural composition of transition zones are acquired.

The outcome of this grant project will be structural modifications of transition zones for various cases of structures of sub-ballast layers. In addition to "geotechnical" measures for the implementation of transition zones, to achieve this goal, attention will also be paid to measures related to the railway superstructure - track skeleton structure (fastening of rails, under sleeper pads). The grant project approach considers the results of the research activities of our Department and also the results of foreign research teams [11-15]. For the design of transition zones, the ŽSR report generally recommends the construction of specially designed and compacted backfills, the so-called wedgeshaped backfills. The design of transition zones is carried out according to [16], where in the case of new constructions, line upgrades and comprehensive reconstructions of existing lines, a design of its length $L=V / 2$ is recommended, (not less than $30 \mathrm{~m}$ and a maximum of $80 \mathrm{~m}$ ).

The paper provides an overview of the determined deformation characteristics of transition zones on one of the most technically demanding sections of corridor line modernization under ŽSR administration. This section contains the majority of artificial structures of the subballast layers, and thus the majority of transition zones. Following the usual practice and technical complexity, the line section Púchov - Považská Teplá was divided into four coherent parts of construction (CPC) Table 1. Each of them was feasible and capable of independent operation with certain limitations and specifications. 
Table 1: Coherent parts of construction and their specification [4].

\begin{tabular}{|c|c|c|}
\hline CPC specification & $\begin{array}{c}\text { Begining of CPC } \\
\text { (new rail km) }\end{array}$ & $\begin{array}{c}\text { End of CPC } \\
\text { (new rail km) }\end{array}$ \\
\hline CPC 44 Track section Púchov - Považská Teplá & 158.398728 & 166.710372 \\
\hline CPC 45 Railway Station Považská Bystrica & 166.710372 & 169.501883 \\
\hline CPC 46 Track section Považská Bystrica - Považská Teplá & 169.501883 & 171.381448 \\
\hline CPC 47 Railway Station Považská Teplá & 171.381448 & 174.318010 \\
\hline
\end{tabular}

Table 2 presents thirteen structures of sub-ballast layers located in CPC 44 and CPC 47 . These are CPC with the occurrence of the predominant part of railway structures of the sub-ballast layers on the line section in question, where the mentioned diagnostics of the construction quality was performed. The structural layers of the transition zones were built of coarse-grained material (crushed aggregate fr. 0/63 mm) into the shape of a wedge backfill. In the case of transition zones for structures of longer lengths (three railway bridges), an inclined reinforced concrete slab (ramp) was applied. In the case of tunnels, the transition zone was established as a cement stabilization of coarse-grained material (crushed aggregate fr. 8/16 mm).

Table 2: Location, designation and type of structures [4].

\begin{tabular}{|c|c|c|c|}
\hline CPC & Stationing (new rail km) & Object designation & Type of structure \\
\hline \multirow{4}{*}{} & 159.038 & SO 44.33 .11 & railway bridge \\
\cline { 2 - 4 } & 159.329 & SO 44.33 .12 & viaduct \\
\cline { 2 - 4 } & 159.630 & SO 44.33 .13 & viaduct \\
\cline { 2 - 4 } & 159.928 & SO 44.33 .14 & viaduct \\
\cline { 2 - 4 } & 160.342 & SO 44.33 .15 & viaduct \\
\cline { 2 - 4 } & 161.215 & SO 44.33 .18 & railway bridge \\
\cline { 2 - 4 } & $161.423-162.506$ & SO 44.33 .30 & railwnel Diel \\
\cline { 2 - 4 } & 162.806 & SO 44.33 .21 .1 & road underpass \\
\hline \multirow{4}{*}{47} & 163.190 & SO 44.33 .21 .2 & passenger underpass \\
\cline { 2 - 4 } & 172.944 & SO 47.33 .12 & railway bridge \\
\cline { 2 - 4 } & 173.02 & SO 47.33 .13 & culvert \\
\cline { 2 - 4 } & 173.962 & 47.32 .12 & railway bridge \\
\cline { 2 - 4 } & 174.220 & 47.33 .14 & \\
\hline
\end{tabular}

\subsection{Methodology for determining the deformation resistance of transition zones}

The construction quality of the structural layers of the transition zones was determined on the section of the railway line Púchov - Považská Teplá using a set for conducting a static load test, Fig. 2.

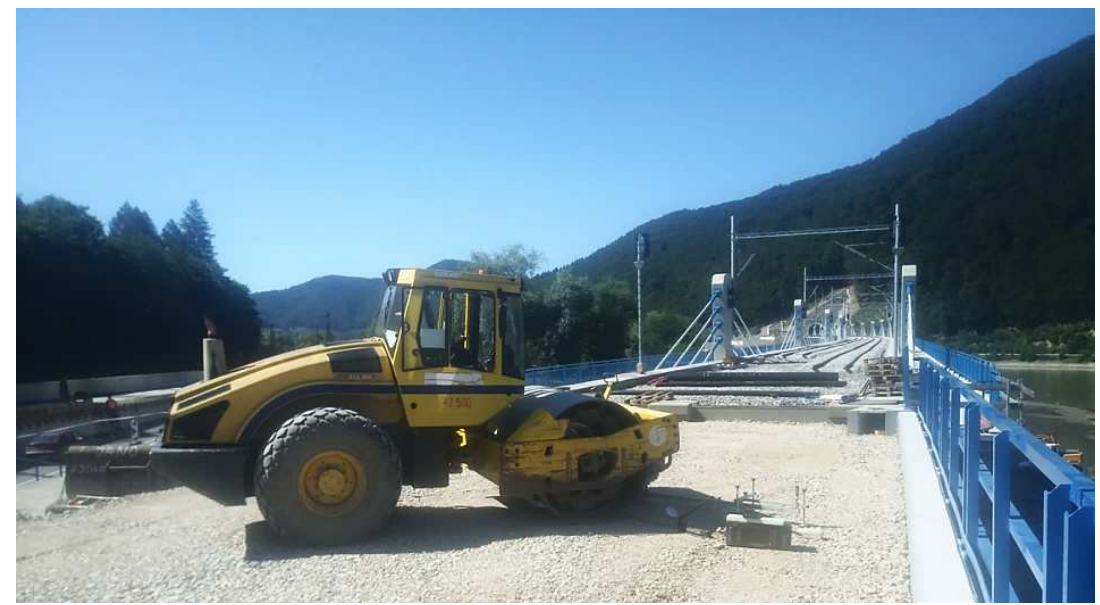

Fig. 2: Conducting a static load test at the level of the sub-ballast upper surface in the transition zone of a two-chamber reinforced concrete bridge (SO 44.33.21). 
Static load tests were performed at the level of the top layer of the material of the embankment body (subgrade surface) and the level of the sub-ballast upper surface, in the earthwork body axis and in the axis of each track, on bridges with larger spans (SO 44.33.11, SO 44.33 .18 and SO 44.33.21) and both tunnels in the track axis at two distances $2.0 \mathrm{~m}$ and $9.0 \mathrm{~m}$ from the beginning of the building, in front of and behind the building (bridge, culvert, underpass, tunnel). The measurement of the deformation resistance of the transition zone at the level of the subgrade surface was carried out according to the methodology given in STN 736133 [17], where during the measurement a rigid circular load plate with a diameter of $357 \mathrm{~mm}$ with maximum contact stress of $0.30 \mathrm{MPa}$ was gradually pushed in two load cycles. The using an appropriate diameter of plate and final level of contact stress [18] play an important role in the testing of deformation properties of standard or new materials [19, 20], or subbase layers of foamed concrete, which is in relation to design of pavements or industrial floors [21]. The measured quantities were the static modulus of deformation $E_{\text {def }}$ and the degree (quality) of compaction expressed by the ratio $E_{\text {def }} / E_{\text {def } 1}$. The static modulus of deformation of the transition zone at the level of subgrade surface $E_{0}$ was determined from the relation:

$E_{0}=\frac{\pi}{2}\left(1-v^{2}\right) r \frac{\Delta p}{\Delta y}[\mathrm{MPa}]$,

where:

$E_{0}$ - static modulus of deformation determined in the whole range of stresses, [MPa],

$v$ - Poisson's ratio determined by the type of the tested material,

$r$ - load plate radius, [m],

$\Delta p$ - change of contact stress, [MPa],

$\Delta y$ - change of the plate settlement (deformation of the tested environment), [m].

The measurement of the deformation resistance of the transition zone at the level of sub-ballast upper surface was performed in accordance with the methodology specified in regulation TS4 Railway Substructure - Annex 6 [22]. During the measurement, a rigid circular load plate with a diameter of 300 $\mathrm{mm}$ was pushed successively in two loading cycles with maximum contact stress of $0.20 \mathrm{MPa}$.

The measured quantities were the static modulus of deformation of the sub-ballast upper surface $E_{\mathrm{s}}$ and the compaction quality expressed by the ratio $E_{s 2} / E_{s 1}$. The static modulus of deformation of the transition zone at the level of sub-ballast upper surface $E_{\mathrm{s}}$ was determined from the relation:

$E_{s}=\frac{1.5 p r}{y}[\mathrm{MPa}]$,

where:

$p$ - contact stress acting on the plate, [MPa],

$r$ - load plate radius, [m],

$y$ - the total average settlement of the load plate determined in the second cycle, [m].

\section{Results and discussion}

The values of deformation resistance of transition zones to the sub-ballast layers structures measured at the subgrade surface level and the level of the sub-ballast upper surface were determined on the modernized line section (specified in detail in section 2.1) from April 2019 to August 2020. To determine the values of static modulus of deformation on the individual levels of the subballast layers of the transition zones, the methodology specified in detail in section 2.2 was used. Fig. 3 summarizes the measured values of the deformation resistance of the transition zones of the individual structures of the sub-ballast layers given in Table 2, set at the subgrade surface level in CPC 44 (interstation section of Railway Station Púchov - Railway Stop Považská Teplá). 


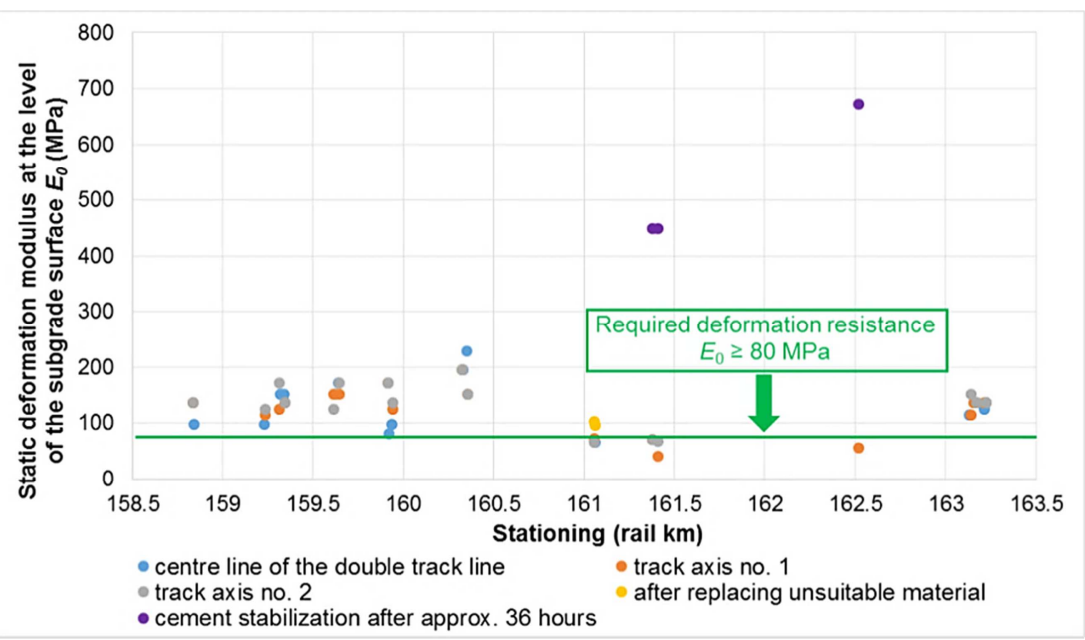

Fig. 3: Measured values of the static modulus of deformation of transition zones at the subgrade surface level on the modernized section of the railway line Púchov - Považská Teplá (specifically in CPC 44).

Fig. 3 demonstrates that out of the nine diagnosed transition zones, in three cases the minimum required values of the static modulus of deformation at the subgrade surface level $E_{0} \geq 80 \mathrm{MPa}$ were not reached. It should be noted that two of these unsuitable transition zones belonged to the Diel tunnel. In its project documentation, this assumed condition was solved by the proposal of cement stabilization of crushed aggregate fr. $8 / 16 \mathrm{~mm}$ in the area of both tunnel portals (purple dots). A third transition zone with unsatisfactory values of deformation resistance measured the level of subgrade surface was identified at building 44.33.21, the longest railway bridge in this structure - over the Nosice dam, at the transition zone located near the portal of the Diel tunnel. In this transition zone of the railway bridge, unsuitable coarse-grained material (high proportion of fine-grained fractions) was subsequently replaced with material of the required quality (suitable grain size curve). Repeated measurements of the deformation resistance in the transition zone then showed the required value of $E_{0} \geq 80 \mathrm{MPa}$ (yellow dots).

In addition to the static modulus of deformation, the degree of compaction of the material built-in the transition zones $E_{\text {det } 2} E_{\text {def } 1}$ was monitored as part of the diagnostics of the quality of the construction layers. The achieved compaction rate of transition zones at the level of subgrade surface was in the range of 1.10 to 2.27 , and thus in all cases of measurements the required compaction rate (quality) for coarse-grained materials $E_{\text {det } 2} E_{\text {def } 1} \leq 2.60$ was achieved.

Fig. 4 presents a summary of the measured values of the deformation resistance of the transition zones determined at the level of the sub-ballast upper surface identified at CPC 44 and CPC 47 (Railway Stop Považská Teplá).

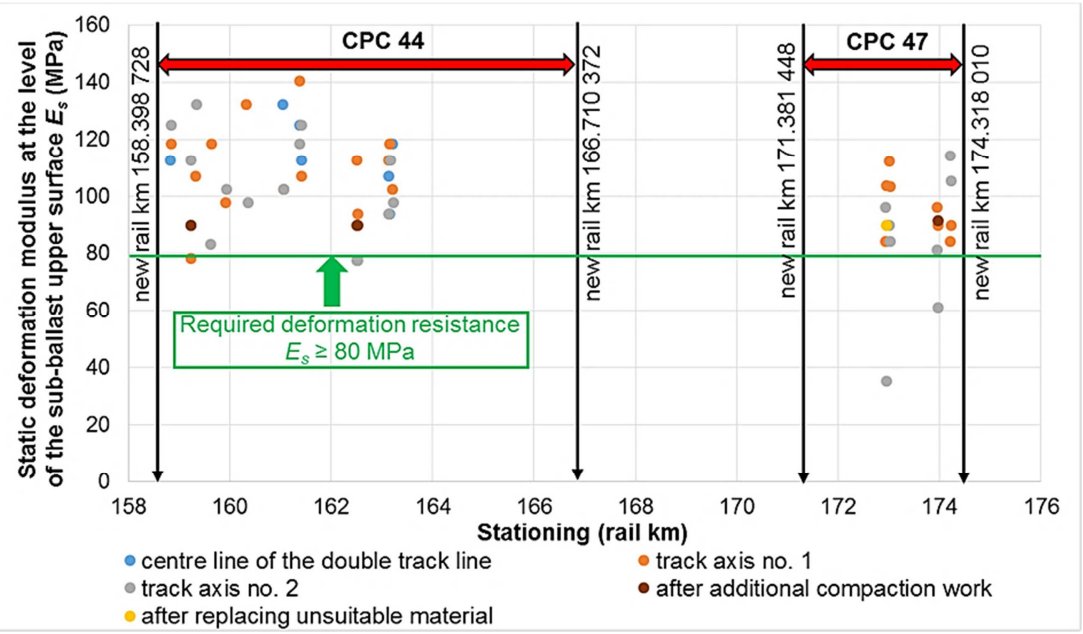

Fig. 4: Measured values of the static modulus of deformation of transition zones at the level of subballast upper surface on the modernized section of the railway line Púchov - Považská Teplá

(specifically in CPC 44 and CPC 47). 
Fig. 4 indicates that four out of the thirteen diagnosed transition zones built of coarse-grained material fr. 0/63 $\mathrm{mm}$ failed from the point of view of achieving the minimum required value of the static modulus of deformation $E_{s} \geq 80 \mathrm{MPa}$ at the level of sub-ballast upper surface. In the three transition zones, the unsatisfactory value of deformation resistance at the level of sub-ballast upper surface was caused by insufficient compaction. After performing further (additional) compaction work, the required values were reached (brown dots). The last unsatisfactory transition zone values, measured at the level of the sub-ballast upper surface, pertained to the passenger underpass (SO 47.33.12) located in CPC 47 (Railway Stop Považská Teplá). In the transition zone in question, unsuitable coarse-grained material (high proportion of fine-grained fraction) was subsequently replaced with material of the required quality (suitable grain size curve). The repeated measurements of deformation resistance showed the required value of $E_{0} \geq 80 \mathrm{MPa}$ (yellow dots). The degree (quality) of compaction of the transition zones determined at the level of sub-ballast upper surface was identified in the range of 1.11 to 2.77 . The required value of the compaction rate for coarse-grained materials $E_{\text {det } 2} E_{\text {def } 1} \leq 2.60$ was not achieved in only one case, in which the value of 2.33 was reached after further compaction work.

\section{Conclusions}

The line section Púchov - Považská Teplá, part of the trans-European corridor no. Va, is technically and financially one of the most demanding modernized sections in the history of the Railways of the Slovak Republic. The purpose of the construction work on this double-track was to modernize its technical infrastructure and achieve the required parameters following the AGC agreement, as well as the legislative documents of the Slovak Republic.

The paper focused on the analysis of measured values of deformation resistance of transition zones on the modernized line section, located at the structures of the sub-ballast layers in CPC 44 (line section Railway Station Púchov - Railway Station Považská Bystrica) and CPC 47 (Railway Stop Považská Teplá). These sections are characterized by the occurrence of the significant number of artificial structures of the sub-ballast layers.

The paper authors appreciate that the ŽSR administration and construction companies implementing modernization work on corridor lines are aware of the importance of the quality inspection of the implementation of structural layers of transition zones. As the diagnostics of transition zones was also performed by DRETM members on the line section Považská Teplá - Žilina (the results are presented in [5]), it can be stated that construction companies implemented the experience gained from this modernized section and achieved more satisfactory results. In the modernized section Púchov - Považská Teplá, in only one out of thirteen assessed transition zones, it was necessary to modify the structural layer material at the sub-ballast upper surface. Other unsatisfactory values of static deformation modulus were removed by further (additional) compaction work.

For the sake of comparison, in the modernized section Považská Teplá - Žilina, it was necessary to replace the subgrade subsoil material in five cases, while fourteen transition zones were assessed. However, in the modernized section Považská Teplá - Žilina, unlike the modernized section Púchov - Považská Teplá, quality diagnostics of the transition zone at the subgrade surface level was not performed. The implementation of diagnostic tests at the subgrade surface level will ensure the achievement of a sufficiently deformation-resistant subgrade of the transition zone and will eliminate the additional costs associated with removing overlaying layers if unsatisfactory deformation resistance of the transition zone is identified at the level of the sub-ballast upper surface.

\section{Acknowledgement}

The presented results are the partial results of solving the VEGA grant project 1/0084/20 Numerical and experimental analysis of transition areas of objects of structures of railway superstructures and objects of formation substructure.

\section{References}

[1] SOSEDOVÁ, J. - ŠLESINGER, J. - GROBARČíKOVÁ, A.: To the European Infrastructure Transport Policy. In: Svet Dopravy (online scientific journal), http://www.svetdopravy.sk/keuropskej-dopravnej-politike-v-oblasti-infrastruktury/. Accessed: February 18, 2021.

[2] European Agreement on Main International Railway Lines. Ministry of Foreign and European Affairs of the Slovak Republic, Geneva, 1993.

[3] REGULATION EU No 1315/2013: Union guidelines for the development of the trans-European transport network. 
[4] Technical reports of railway line Púchov - Považská Teplá modernization.

[5] IŽVOLT, L. - DOBEŠ, P.: Analysis of results of deformation characteristics measurements of embankments and transitions zones of a modernised line Považská Teplá - Žilina. XII International Conference: Transport Problems, Katowice, Poland, 2020, pp. 275-284.

[6] Mapy.cz: 3D winter map, https://sk.mapy.cz/zimni? $x=18.3900057 \& y=491380702 \& z=14 \& m 3 d=$ 1\&height $=7329 \&$ yaw $=-1 \&$ pitch $=-55 \& l=0$. Accessed: 18 February 2021.

[7] LUNDQVIST, A. - DAHLBERG, T.: Load impact on railway track due to unsupported sleepers. Proceedings of the Institution of Mechanical Engineers, Part F. Journal of Rail and Rapid Transit, Vol. 219, Iss. 2, 2005, pp. 67-77, https://doi.org/10.1243/095440905X8790. Accessed: 18 February 2021.

[8] VARANDAS, J. N.: Long-term behaviour of railway transitions under dynamic loading. Ph.D. Thesis, Nova University of Lisbon, Portugal, 2013, https://run.unl.pt/bitstream/10362/10145/1/ Ferreira_2013.pdf. Accessed: 18 February 2021.

[9] ŠESTÁKKOVÁ, J.: Quality of Slab Track Construction - Track Alignment Design and Track Geometry. Civil and Environmental Engineering, Vol. 11, Iss. 1, 2015, pp. 2-9, https://doi.org/10. 1515/cee-2015-0001. Accessed: 18 February 2021.

[10] ŠESTÁKOVÁ, J. - MEČÁR, M.: Evaluation of Track Design and Track Geometry of the Track with Unconventional Structure of Railway Superstructure. Procedia Engineering, XXIV R-S-P seminar: Theoretical Foundation of Civil Engineering, Vol. 111, 2015, pp. 709-716, https://doi.org/ 10.1016/j.proeng.2015.07.136. Accessed: 18 February 2021.

[11] PAIXĂO, A. - FORTUNATO, E. - CALÇADA. R.: Transition Zones to Railway Bridges: Track Measurements and Numerical Modelling. Engineering Structures, Vol. 80, 2014, pp. 435-443, https://doi.org/10.1016/j.engstruct.2014.09.024. Accessed: 18 February 2021.

[12] SHAHRAKI, M. - WITT, K. J.: 3D Modeling of Transition Zone between Ballasted and Ballastless High-Speed Railway Track. Journal of Traffic and Transportation Engineering, Vol. 3, 2015, pp. 234-240, https://doi.org/10.17265/2328-2142/2015.04.005. Accessed: 18 February 2021.

[13] VARANDAS, J. N. - HÖLSCHER, P. - SILVA, M. A. G.: Dynamic Behaviour of Railway Tracks on Transitions Zones. Computers and Structures, Vol. 89, 2011, pp. 1468-1479, https://doi.org/10. 1016/j.compstruc.2011.02.013. Accessed: 18 February 2021.

[14] WANG, H. - MARKINE, V. L.: Modelling of the Long-Term Behaviour of Transition Zones: Prediction of Track Settlement. Engineering Structures, Vol. 156, 2018, pp. 294-304, https://doi. org/10.1016/j.engstruct.2017.11.038. Accessed: 18 February 2021.

[15] WANG, H. - MARKINE, V. L. - LIU, X.: Experimental Analysis of Railway Track Settlement in Transition Zones. Journal of Rail and Rapid Transit, Vol. 232, Iss. 6, 2018, pp. 1774-1789, https:// doi.org/10.1177/0954409717748789. Accessed: 18 February 2021.

[16] Slovak Railway Regulation TNŽ 73 6312: The design of structural layers of subgrade structures. Directorate General of Railways of the Slovak Republic, Slovakia, 2005 (in Slovak).

[17] STN 736133 - Road Building. Roads embankments and subgrades. Standard, Slovak Office of Standards, Metrology and Testing, Slovakia, 2017 (in Slovak).

[18] DECKÝ, M. - DRUSA, M. - PEPUCHA, L. - ZGUTOVA, K.: Earth Structures of Transport Constructions. Pearson Education Limited, Harlow, 2013, 180 p.

[19] HÁJEK, M. - DECKÝ, M. - DRUSA, M. - ORININOVÁ, L.: Elasticity modulus and flexural strength assessment of foam concrete layer of POROFLOW. IOP conference series: Earth and environmental science, Vol. 44, 2016.

[20] KAWALEC, J. - KWIECIEN, S. - PILIPENKO, A. - RYBAK, J.: Application of Crushed Concrete in Geotechnical Engineering - Selected Issues. IOP Conference Series: Earth and Environmental Science, Vol. 95, Iss. 2, art. no. 022057, 2017, pp. 1-10, https://doi.org/10.1088/1755-1315/95/2/ 022057.

[21] HÁJEK, M. - DECKÝ, M. - SCHERFEL, W.: Objectification of modulus elasticity of foam concrete Poroflow 17-5 on the subbase layer. Civil and Environmental Engineering, Vol. 12, Iss. 1, 2016, pp. 55-62, https://doi.org/10.1515/cee-2016-0008.

[22] Slovak Railway Regulation TS4 Track substructure - Appendix 6. Directorate General of Railways of the Slovak Republic, Slovakia, 2018 (in Slovak). 